\title{
The Review of European Community and European Union Through the Prism of Common Market
}

\author{
TOTIC Mirza ${ }^{1}$
}

${ }^{1}$ State university of Novi Pazar, Novi Pazar, Department of law (SERBIA)

Email:mirzatotic@yahoo.com

\begin{abstract}
The paper deals the characteristics and significance of the common market, which was the main objective while forming the European Economic Community (EEC), and institute with no alternative for the functioning of its successor - the European Union (EU). The research approach to this institute of international rank is fundamentally critical. The main reason for that view is disagreement with the claims that in internal market there are all types of business relationships and various transactions among Member States, without restrictions, problems and discrimination. The purpose of the paper is to look at market activities and identify problems that are their inevitable followers, the evaluation and affirmation of success, and identification of deficiencies. The aim of the paper is to look for an answer to the question: whether a single (internal) market really obliges each Member State to move towards the defined objectives, same directions, and whether it succeeds in standardizing its internal market, in order to make it compatible with the objectives contained in the Treaty establishing the European Economic Community (EEC).
\end{abstract}

Keywords: Common Market, European Economic Community (EEC), European Union (EU), Single European Act, "four freedoms"

JEL: P20

UDK: 339.923:061EU

\section{Introduction}

Most of the stories about European integration begin with important events that took place after the end of the Second World War. Certain authors [1] see the beauty of the formation of European Economic Community (EEC): “... in its originality, simplicity and the chosen way ... which before has never been exposed to history check... it is the integration of different nations on a voluntary basis". Others think that the first step in this direction was made by Winston Churchill (Winston Leonard Spencer Churchill) while giving his famous speech at the University of Zurich (Switzerland) on September 19, 1946. The majority of people claims that Treaties signed in Rome in 1957 are actually recognized as legal documents that formally marked the establishment of the European Economic Community (EEC), since they contained all necessary legal, institutional and material provisions. Without any doubt, this was a very significant event, but it seems that the main one is being forgotten, the one that had turned the European globe around. It is a meeting of the famous Bilderberg group in 1954, held at the Bilderberg Hotel in Arnhem (Netherlands). This group has no official name, except for the aforementioned, which was obtained according to the location of its first meeting, when the decision on formation of the European Community was made. Accordingly, many theorists 
claim that only after this event we can talk about the power of the Rome treaties and all others that will mark the integration processes in the second half of the XX century.

However, the focus of discussion is on the term, characteristics and significance of the common market, an institute created for the benefit of all Member States of the European Economic Community/Union. There should be no doubt that the establishment of a single or internal market represents the best intention in order to secure free movement of people, goods, services and capital, as well as within the borders of any European country individually. Still, remains dilemma concerning the prohibition of discrimination for which is believed that will be present until certain Member States enjoy the right to any kind of national sovereignty.

\section{Formal Characteristics of the Common Market}

The signing of the Treaty establishing the European Economic Community (EEC) in Rome by six European countries (Germany, France, Italy, Netherlands, Belgium, Luxembourg) marked the setting up of ambitious economic goals, followed by (with fewer restrictions) political ones. The economic objectives of the newly established European Economic Community (EEC) were strictly defined in the introductory provisions of Article 2 of the Treaty. It is a very wide range of goals:

1. Encouraging a balanced and sustainable economic and social growth and high level of employment,

2. confirmation of its own identity on international economic-political scene through special conduct of a common foreign and security policy,

3. strengthening of the protection of rights and interests of nationals of Member States by establishing the right of citizens of the European Economic Community (EEC) and

4. strengthening of the European Economic Community (EEC) as a place of freedom, and

5. comprehensive preservation of acquis communautaire and its further development [2].

Grosso modo all goals are directly related to the establishment of common market, introduction of economic and monetary union and implementation of common policies and activities in Member States. The importance of the common market and its relation to other objectives of the European Economic Community (EEC) is best illustrated by the fact that for a long time in all communications, the European Economic Community (EEC) and the common market have been simply identified. Accordingly, the Community is actually an internal market, as within the latter the international trade between Member States is not disturbed by customs duties or quotas, while investments are directed to places where conditions for the functioning of "four freedoms" are ensured in the atmosphere of free competition. Kovač [3] says: "... that the internal market was not known in theory as an institutionalized degree of economic integration ... so it can be considered as an intermediate or process of becoming an economic and political union, and not a final economically independent goal of the Member States ... the market as an economic category exists totally with all accompanying attributes or does not exist, so in that sense it could be compared with gestation ... Gestation either exists or does not exist ... and to be only in half state of gestation is impossible". Therefore, the establishment of market could not stay in a halfway. If the market really is a market, then it has to be unique, and if it is not unique then it is not a market and therefore the effects are absent like it does not exist. It seemed that Single European Act (SEA) signed in 1986 defined internal or single market in a simple and functional way, as a space without borders between Member States where the free movement of goods, persons, services and capital is guaranteed [4]. But it only created a big dilemma for which the legal theory had no effective solution. It initiated a conflict of opinions [5] whether the notion of internal market is narrower than the term of common market. Therefore, in the literature, when determining its significance, it was possible to find and, therefore, distinguish two methodological approaches. 
The first one, very spacious, implied finding and comparing of the similarities of its content with the content of the previously introduced term, a common market, within which there are also different opinions and opposing attitudes. Advocates of the rigid claim have no doubt that the term of internal market is much narrower than the concept of common market [6] because the internal market is not able to encompass all common policies (social, fiscal or agricultural), while it is easy for the common market to do so. The common market is a wider concept, because the countries renounce certain market prerogatives due to their membership [7] which automatically become an integral part of it. The rigid attitude is opposed by a more flexible one, that the single market is considerably deeper than the common, since it implies the abolition of even last obstacle that could be legitimate in the common market, especially if it contains presumed measures that contribute to the achievement of economic, legal and social cohesion in the Community. The last opinion is finally pacifying [8] because according to its followers, the concepts of common and internal market are identical, and therefore there is no need, after the common market has been established, to proclaim the internal market as an entirely new goal.

According to the second, functional methodological approach, the internal market is defined first, in accordance with the final goal whose realization is expected in a given period of time. A functional approach was used by the European Court of Justice in one of the first cases (Van Gend en Loos 26/62, 1963) when it was noted that the objective of the Treaty establishing the European Economic Community (EEC), was the creation of a common market whose direct functioning concerns only the Member States. Such cases that have enriched the European Court of Justice jurisprudence and justified the institutional nature of the European Court of Justice are numerous and they have served in some way to regulate the rules and to enact acts and documents on which the market is based, regardless of its name.

On several occasions, the European Court of Justice has emphasized the similarity between the concepts of a common and unique market by asserting [9] that the Treaty aims by establishing the common market and gradually harmonizing the economic policies of Member States to consolidate national markets in one single market that would have characteristics of domestic one ... Common market of the European Economic Community (EEC) is described as a space without barriers to trade within its borders, that is, a truly internal market in which all national markets should be included. Barents [10] claims that the European Court of Justice was practically forced to take the stand, that realization of the internal market refers to the establishment and functioning of a common market, which practically means that between not only concepts but institutes there is also a sign of equality.

Another approach in order to define a common market comes from the degree of individual economic freedoms and conditions created for their enjoyment. Therefore, the common market is a deliberately determined area where all participants must be absolutely free to invest, borrow money, work, offer, sell or buy goods and services in any place in the Community. Within it, they all enjoy equal rights and freedoms, and are individually managed according to the economically most favorable conditions determined by the conflict of supply and demand.

Any form of market linkage, whether in common or internal market of the European Economic Community (EEC), and later the European Union (EU), Member States saw as an area where they could easily achieve, firstly, all their economic goals and then directly affect the creation of surroundings for achieving other, common goals. This is how the easy process of establishing and functioning of internal market has created the conditions in which has occurred the gradual immersion of various national markets in a single (marché unique) or internal market (marché intérieur). The basic message of its establishment was that there was no difference between market entities and that to all were allowed equal conditions for carrying out economic activities regardless of where they came from and to whom they belonged. The internal market is characterized by the fact that it indirectly forced third non-member countries 
to different market behavior and to change the organization of internal, national market in order to adapt to its conditions in a more efficient way. Non-member countries that managed to recompose their market behavior in a timely manner were more easily adapted to new business rules in the internal market of European Economic Community (EEC), so they have managed to create within their borders the similar conditions to those in the markets of Member States. Obviously, the internal market of the European Economic Community (EEC) is further confirmed as a very important factor of integration not only between Member States, but also in non-member state - Member State relations. Its special quality is the direct and indirect creation of conditions in which the inter-state political rapprochement [11] is very convincingly induced, since through the turbulent legal, and then political process creates a cohesive union with a harmonized or unified communitarian legal system.

The critical attitude towards the aforementioned claims refers at first place to the position of third non-member states through the question: are they and to what extent discriminated in organizational, economic or political way? They are discriminated, because it is impossible to avoid the fact that for their economic strength (goods, services, people), the establishment of internal market within European Economic Community (EEC) is nothing but raising of the ramp [12] to take part in supply and demand, or building a European trade fortress (forts commerciales europeennes). Given that for the third countries, the principle of "four freedoms" has no relevance, many, when they were able, applied protectionist policy measures in order to protect national market. In that sense, the European Commission (EC) already in 1985, while analyzing this issue from the point of view of the interests of Member States of the European Economic Community (EEC), emphasized: “... that the trade identity of the Member States and identity of the European Economic Community (EEC) must be established so that their trading partners can not realize the benefits of the wider market without giving similar benefits" (White Paper, 1980), which is essentially a highlight of the policy of strict reciprocity.

\section{European Single Act, Changes and Violations of the Integrity of "Four Freedoms"}

Single European Act is an agreement signed by Member States in order to eliminate problems that have devastated the concept of "four freedoms" and slowed free trade flows beyond the borders of the European Economic Community (EEC) through a multi-year program. Its adoption finally restricted the international space in the form of a future single market where the same rules should apply, for example, on foreign trade for all Member States. Formally, this was the document whose adoption meant the first modification of the Rome Treaty on the European Economic Community (EEC). Having laid down the legal foundations on which the future single market should been postulated, it clearly defined the new competences of Community (social policy, economic and social integration, research and technological development, environmental protection), initiated cooperation in the area of foreign policy, expanded the powers of the European Parliament and simplified the decisionmaking process of the Council of Ministers. This explains that all European Economic Community (EEC) institutions and documents have to be based on law, so it was more precise to call it a community based on administrative law (communauté fondée sur le droit administratif). Practically, from its foundation (until the change of name), it was nothing but administrative law community. In the beginning, administrative law was under considerable pressure of comparative law and only through the institutions of the European Union (EU) it managed to overthrow the cover of national isolation, which overcame former narrow aspects and opened up significant developmental perspectives [13].

The 1980's in Europe were often called "turbulent" because they were marked by very important events, popularly called "filthy revolutions," [14] which radically changed the flows and development of the European Economic Community (EEC). However, the biggest political 
event that marked the $\mathrm{XX}$ century, for which there is an academic consensus, was the demolition of the Berlin Wall, that since 1961 when built, symbolized interstate antagonism and Cold War. That cold November 9, 1989, Europe literally exploded politically, and the "iron curtain" had to fall because of the strong detonation [15]. One year later, East and West Germany reunited, which to malevolent seemed as the announcement of creation of a new great economic empire, since after many decades through the Branderburg Gate in Berlin members of the German people were passing again, just until yesterday separated on two sides, strictly controlled with artificial boundaries. Although reunited, they were not alone.

They were "reinforced" by billionaires tycoons and criminals predominantly from the former Soviet Union, "hungry" for European life, reckless, with full bags of dirty, oil-soaked money, who were crossing Europe and seeking opportunities to invest crime-funded financial capital into English and French stables, football clubs, coastal resorts and luxury vessels in the Mediterranean belt. Therefore, it is so important to avoid one of Europe's biggest misconceptions: that the emergence of large multinational companies, new figures in economic, sports, political life and the circulation of fascinating amounts of dirty money, was the success of organized and communitarian law of a single European market. Everything else might be, but this certainly not. Eliot [16] does not say by chance: “... that place where legal business stops, and arises unlawful, becomes increasingly blurred, so it cannot be easily detected".

Therefore, all mentioned circumstances imposed the unexpected obligations to Community which is why the latter had to expand its activities outside of economic sphere [17].

Accordingly, the form of the previous founding treaty was changed, since on February 7 , 1992, the new one was signed in Maastricht (Netherlands), which came into force on November 1, 1993. The Treaty establishing the European Economic Community was amended as follows: "... instead of the name" European Economic Community (EEC), will be used the term "European Union (EU)" .The internal market (marché intérieur, Biennenmark) is regulated as an area without internal borders, where the free movement of people, goods, services and capital is guaranteed, in accordance with the provisions of the new treaty and in the terminological approach (internal or common) there were no specific changes, which means that there are no significant differences in that sense. This is the same goal, so there were no obstacles in the equal use of both terms and their further equal existence [18]. After all, there are many documents and significant sources that the European Economic Community (EEC) has previously used, and the European Union (EU) is still using, in which both terms are treated equally. This means that the market name does not change its essence, function and role, which is the winning argument [19]. Whether being unique or internal, it is only a form of economic integration [20] that by abolishing technical and administrative barriers, has led to the creation of a common market within the territory of the participating states. When all the circumstances are brought together, it is possible by using deductive method to conclude that establishment of the internal market should serve to create optimal conditions for the smooth functioning of economic and monetary union, which practically led to the introduction of the single currency $(€)$. For the latter, the name (internal, common, unified) or the origin (national, territorial) has no importance, it is solely a matter of its market role.

\section{Internal Market - a Paradigm of Integration Processes}

Common market as an opportunity, characteristic of federally organized economies that strive to maintain the economic balance between economic interests and political desire for communion, neither as a concept nor as institution is unknown or original [21]. Initiatives for its establishment are historically early dated, and therefore it is anomalistic, the establishment of the European Economic Community (EEC) to take as the primary reason for its creation. 
Namely, even before there were successful and unsuccessful attempts to establish more solid or loose alliances and/or unions, for example, the customs union of the German states (Zollverein) or the customs union of the Benelux states (Belgium, Netherlands and Luxembourg), which was established after signing by the three governments in exile in 1944 in London (United Kingdom). The agreement entered into force in 1947. Accordingly, if the European Economic Community (EEC) is unacceptable as a paradigm for the establishment of a common market, there is no reason not to be the standard of economic integration that has had a major impact on all other forms of international connectivity. This is why the economic theory all integrations in European Economic Community (EEC) measured by the strength of the bonds between the Member States and through the free trade area, common market, customs, political and economic union.

The common market is an important factor that contributes to the smooth running of free trade. It does not endure any obstacles in trade and other relations between Member States, and if they happen to exist, then they impose the need for its immediate removal. On the other hand, it does not prevent Member States from independently defining their own trade policies towards non-member countries and to conclude different business arrangements and international agreements and contracts with them [22]. Member States of the European Union (EU) can, without any problems, establish various types of business contacts [23] with the European Free Trade Association (EFTA), the Latin American Free Trade Association (LAFTA) or the North American Free Trade Zone (NAFTA). By establishing intergovernmental trade contacts with these zones outside Europe, Member States contribute to its affirmation, which everyday confirms its role in creating a large number of opportunities for the promotion of not only international trade relations, but also other forms of human activities. To become common in the true sense of the word, the market had first to be deprived of customs, to eliminate most trade restrictions if there were any and to install a common tariff system [24] for third countries, non-members. These processes took place in stages, with the establishment of a customs union for industrial products on July 1, 1968, and then on January 1, 1970 when was officially expanded to all other products. The establishment of common customs tariff system has given the European Economic Community (EEC) a double benefit.

First, it provided the primary source of financial funds, and secondly, it received wider jurisdiction in negotiating and concluding a customs-related treaty with third countries and international organizations. The creation of customs union did not go easy, but it was not carried out quickly and without a strategy. It turned out to be correct that only the gradual abolition of barriers could have a positive effect on the smooth conduct of international trade and establishment of other business relationships. Their abolition, without major earthquakes, contributed to the increase in trade and financial transactions not only between Member States, but also with the rest of the world, to increase in the supply (demand) of goods and services and in achieving a greater volume of financial and other benefits for all market participants. According to [25] for a period of less than three decades (1958-1985), part of the total exports of the ten Member States of the European Economic Community (EEC) increased from 35\% to $53 \%$, which resulted in increased participation in gross domestic product (GDP) from $4.9 \%$ to $14 \%$. In 1985, the European Economic Community (EEC), officially (and expected), became the largest trading block in the world with nearly 320 million inhabitants and with $20 \%$ of its share in world foreign trade, just after the United States of America (USA). Opposite to the customs union, there was a completely logical political union that, from the legal and political point of view, implied the existence of a single nation and central government. Its task was to fully control the implementation of monetary and fiscal policy measures, which, politically speaking, was identified with the role of central parliament. Therefore, a complete unification of monetary and fiscal policy was achieved between all Member States [26]. Thus, it would be non-academic at the very end to neglect the fact that all these forms of international integration 
could be achieved exclusively with positive and negative measures (Craig, 2002), by elimination of many barriers in trade between Member States, changing of existing instruments and institutions and creating and introducing new ones. The community has gone through all the necessary phases, and for the realization of common goals, it was forced to adopt a series of legal and technical regulations, firstly in industrial and agricultural production, and then in trade and transport.

\section{Conclusion}

The development path and the process of functioning of the common market was not deprived of difficulties, as it has been hindered in many Member States by technical, regulatory, legal and bureaucratic obstacles. In particular, international trade was restricted, which directly affected the status of four aforementioned freedoms. For these reasons, Member States and institutions of the European Economic Community (EEC), together and continuously from 1985 to 1992 , have tried to remove them, to create a clean space and provide the necessary ambience for the smooth functioning of the common market. Success was not missed. According to the European Commission, since the signing of the Treaty in Maastricht (The Netherlands) on February 7, 1992, the single market has enabled the creation of more than 2.5 million new jobs and generated over 800 billion euros of additional material wealth in Member States. With the elimination of national restrictions, at least 15 million Europeans have been given a unique opportunity to work and live in one of the Member States of the European Economic Community (EEC). Academic authorities in financial and political literature for decades suggested that European Economic Community/Union looked like the entrance part of a Greek temple lying on three pillars, which was effectively used in Maastricht in 1992 to formulate its structure, but also architecture. The first pillar was of a supranational nature, and was legally based on the Treaty on the European Economic Community (EEC) and the Treaty on the European Atomic Energy Community (EUROATOM). The second pillar symbolized the cooperation of Member States in foreign and security policy, and the third involved cooperation in the domain of state police and judicial institutions in charge of criminal and other legal proceedings.

The need to reduce or fully eliminate differences between the regions was particularly emphasized while concluding Treaties of Rome, which was continued after the adoption of the Single European Act, in order to speed up integration processes on the economic and social agenda. This resulted in a significant change in the conduct of the financial policy, which ultimately relied on financial solidarity, by allocating part of the funds paid by Member States to the European Economic Community (EEC) budget to less developed regions and nonmember countries. The single market as the greatest achievement of the Community has allowed the removal of trade barriers and welfare among people across the continent, as well as the international recognition of many Member States and has undergone a real revolution in achieving brilliant results (finance, communication, smart technology) that touched every segment of European man's life.

\section{REFERENCES}

1. Moussis, Nicolas. Handbook of the European Union, European Study Services, 1994, p. 14.

2. Raymond, F. Mikesell. (1958). The Lessons of Benelux and the European Coal and Steel Community for the European Economic Community. The American Economic Review, Vol. 48, No. 2, Papers and Proceedings of the Seventieth Annual Meeting of the American Economic Association (May 1958), pp. 428-441.

3. Kovač, O. (1994). "Konstitutivni elementi jedinstvenog tržišta u Evropskoj uniji i u SR Jugoslaviji”, u zborniku: Pravni i ekonomski okviri uključivanja jugoslovenskih privrednihsubjekata u unutrašnje tržište Evropske unije, Pravni fakultet u Kragujevcu, Institut za pravne i društvene nauke, Kragujevac, 1994, str. 23. 
4. Ehlermann, Claus-Dieter. (1987). The Internal Market Following the Single European Act. (In: Common Market Law Review 24:3, pp. 361-409).

5. Mortelmans, Kamiel. (1998). The Common Market, Internal Market and Single Market, What's in a market? CMLRev, p. 107.

6. Pescatore, Pierre. (1987). Some Critical Remarks on the "Single European Act", 24 CMLRev, p. 11.

7. Totić, M. (2018). Nezaposlenost kao ograničavajući faktor savremenog privrednog razvoja. Međunarodna naučna agrobiznis konferencija MAK 2018, "Evropski put-put uspeha”, Kopaonik 25-26 januar 2018.

8. de Ruyt, J. (1987). L’ Acte Unique Europeen, Brusells, p. 150.

9. Vukadinović, Radovan. (2008). Uvod u institucije i pravo Evropske unije. Centar za pravo Evropske unije Pravnog fakulteta u Kragujevcu, str.158.

10. Barents, Rene. (1993). The Internal Market Unlimited: Some Observations on the legal Basis of Community Legislation, 30CML Rev85, p. 103.

11. McGee, Andrew and Weatherill, Stephen. (1990). The evolution of the single market: Harmonization or liberalization. Modern Law Review, vol. 53, p. 578.

12. Toulemon, R. (1996). "The Balance between 'Small Nations' and 'Large Nations' in the European Union." Futuribles 206 (February 1996): pp. 23-46.

13. Scwarze, Jurgen. (1992). European administrative Law, Office for Official Publications of the European Communities, Sweet and Maxwell, London, pp. 3-4.

14. Vaneigem, Raoul. (1967). The Revolution of Everyday Life (“Traité de savoir-vivre à l'usagedes jeunes générations"), 176: Red and Black, p. 279).

15. Shirer, L. William. (1990). The Rise and Fall of the Third Reich: A History of Nazi Germany, Simon and Schuster, pp. 598-610.

16. Eliot, A. Mejb. (1962). Crime in Modern Society, Svjetlost, Sarajevo, p. 114.

17. Kapteyn, P., Joan, George, Themaat, van Pieter, Verloren. (1989). Introduction to the law of the European communities after the coming into force of the Single European Act. Kluwer Law and Taxation, p. 122.

18. Official Journal C 340 of 10 November 1997.

19. Weeatherill, Stephen. (2002). 'Pre-emption, Harmonisation and the Distribution of Competence to Regulate the Internal Market'. (In: Barnard, Catherine \& Scott, Joanne (eds), The Law of the Single European Market (Hart Publishing, 2002), pp. 41-73.

20. Musgrave, Peggy. (1967). Harmonization of Direct Business Taxes: Aase Study, in: Shoup C. S., Fiscal Harmonization. (In: Common Markets, Volume II, Columbia University Press, p. 210.)

21. Lasok, Dominick and Bridge, John William. (1991). The Law of the Economy in the European Communities; Austin, London, p. 51.

22. Alter, J. Karen. (2000).“The European Union's Legal System and Domestic Policy: Spillover or Backlash.” International Organization 54 (Summer 2000), pp. 489-518.

23. Kassim, H. (1994). "Policy, Networks and European Union Policy Making: A Skeptical View." West European Politics 17 (October 1994): pp. 15-27.

24. Wilkin, Phil. (2003). "European Integration, 1945-2003: From the European Economic Community to the European Union.” Choice 40: pp. 1851-1866.

25. Lopez-Claros, Augusto. (1987). The European Community: On the Road to Integration, Finance and Development, No 3., p. 36.

26. Radaelli, M. Claudio. (1999). "The Public Policy of the European Union: Whither Politics of Expertise?" Journal of European Public Policy 6 (December 1999): pp. 757-774.

\section{Article history:}

- Received 20 September 2019

- Accepted 28 November 2019 